\title{
Should the Responsibility to Protect be Enshrined in International Law?
}

\section{Amanda Lo \\ Bachelor of Arts, Government \\ Georgetown University, 2013}

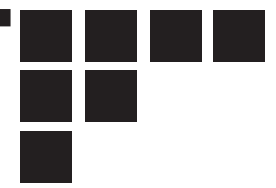

While states admit a moral responsibility to take action against states that violate human rights and international criminal law, international law does not create any legally binding obligations on states to prevent or punish violators of human rights. Yet, enshrining the "responsibility to protect" in international law will only threaten the stability of the international system that has long operated based on the norm of state sovereignty and the principle of non-interference.

The structure of the paper is as follows. First, I will discuss the historical background that gave rise to the concept of the "responsibility to protect" in order to understand its purpose and definition. Next, I will address the inherent tensions found within the responsibility to protect, and will focus on the tensions between the moral responsibility versus legal responsibility of states when they are faced with the "responsibility to protect". Through the case of Libya, I argue that humanitarian concerns do not override the importance of the principle of state sovereignty. Finally, I suggest what the international community can do to fulfill their moral duties without undermining state sovereignty.

I.

The international community realized that its failure to protect civilians during the $20^{\text {th }}$ century led to disastrous outcomes. "Never again" would the world let events as horrible as the Holocaust, the Cambodian genocide of the 1970s, and the 1994 Rwandan genocide be repeated. The doctrine of the "responsibility to protect" emerged from this background as the United Nations and its member states sought to improve their responses to mass atrocities.

The central tenet of the responsibility to protect is based on two ideas: "sovereignty as responsibility" and human security.
Sovereignty as responsibility is the idea that state sovereignty entailed responsibilities, which governments are held accountable for. In particular, states are responsible for the human security of their citizens, meaning governments need to guarantee the basic human rights, dignity and worth of every human person.

According to the responsibility to protect, it is a primary responsibility of a state to protect its own citizens from four serious crimes: genocide, war crimes, crimes against humanity and ethnic cleansing. ${ }^{1}$ The principle of responsibility to protect is based on three pillars ${ }^{2}$ : first, it is the primary responsibility of a state to protect its population from the four crimes listed above, genocide, war crimes, crimes against humanity and ethnic cleansing. Second, the international community is responsible for assisting states to meet their responsibilities. Third, when a state has manifestly failed to protect its population from these crimes, the state has abrogated its sovereignty, and the international community has a responsibility to take timely and decisive action through appropriate diplomatic, humanitarian and other means under Chapter VI and VIII of the UN Charter, and appeal to stronger measures under Chapter VII, which include the collective use of force authorized by the UN Security Council. 
II.

One of the biggest challenges of implementing the responsibility to protect is the unresolved tensions between a state's moral duty versus its legal obligation when it is faced with the "responsibility to protect". In general, states acknowledge there are moral imperatives in responding to mass atrocities. However, the legal responsibility to respond to widespread human rights abuse taking place in another sovereign state is weak, and almost nonexistent under existing international law.

The moral imperative for states to prevent such horrible crimes from repeating is well documented, and most states have signed and ratified to treaties designed to protect civilians in armed and non-armed conflicts. In the post-World War II international system, with the UN Charter as the basis of the international legal system, states have sought to avoid a repetition of the scale, intensity and duration of the brutality inflicted on civilians during World War II. In this spirit, a series of

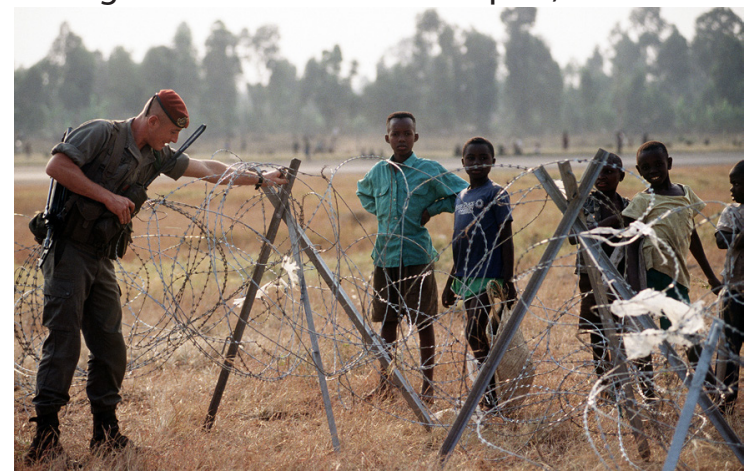

A French marine, part of the international force supporting the relief effort for Rwandan refugees

legal documents have been produced over the years that reaffirm the United Nations and its member states' commitment to limiting abuses on civilians. The passage of the Universal Declaration of Human Rights and the Convention on the Prevention and Punishment of the Crime of Genocide in 1948, the Geneva Conventions in 1949, the Hague Conventions, as well as the prosecution and creation of war crime tribunals show a strengthening of international humanitarian and criminal law. These are some of the most ratified treaties, and provide strong evidence that states realize their moral duties to prevent the innocent deaths of civilians. Furthermore, the United States, which has long provided leadership in global humanitarian issues, has continued its commitment to preventing mass atrocities. In 2011, President Obama reaffirmed the responsibility of the United States in atrocities prevention, authorized the creation of an interagency atrocities prevention board, and cited that "preventing mass atrocities and genocide is a core national security interest and a core moral responsibility of the United States." ${ }^{\prime 3}$ Importantly, the President did not make reference to the legal responsibility to prevent mass atrocities and genocide. The existence of a legal responsibility for states to respond to atrocities is the topic that I will address next.

While the responsibility to protect builds upon this common understanding that states have a moral duty to prevent civilians from unjustified human rights abuse, the legal basis for states to respond to mass atrocities is extremely weak. Our legal understanding of the responsibility to protect is based on four documents. The document that first introduces the concept is the International Commission on Intervention and State Sovereignty's 2001 report, The Responsibility to Protect. ${ }^{4}$ The second document was produced in December 2004 during a debate on United Nations reform, and the High-Level Panel on Threats, Challenges and Change reinforced the concept in its report, A More Secure World: Our Shared Responsibility. ${ }^{5}$ The third document is a 2005 report of the UN Secretary-General called In Larger Freedom: Towards Development, Security and Human Rights for All. ${ }^{6}$ The report states that the security of states and that of humanity are indivisible and that collective action is necessary in order to solve threats facing humanity. It emphasizes that the responsibility to protect must be embraced and acted on when necessary. The fourth document, the Outcome Document, was produced after a high-level meeting of the General Assembly in September 2005.? 
Paragraphs 138 and 139 in the Outcome Document recognize that each state is responsible for protecting its citizens from crimes of genocide, war crimes, ethnic cleansing and crimes against humanity, and determined that the international community also had a corresponding responsibility.

While the doctrine of responsibility to protect and these four documents seem to reinforce the idea that the international community has the responsibility to take action when a state fails to protect its citizens, in reality, there is little evidence that states have the legal duty to take action. If foreign states do not live up to their responsibility to protect and take collective action, they do not face any kind of sanctions, which suggests that the responsibility to protect cannot even be considered anywhere close to a primary norm in international law. Therefore, it is extremely hard to prove that states have a positive duty to take collective action. No specific consequences are attached to a state's failure to act according to the ILC Articles on State Responsibility. Furthermore,

\section{It is extremely hard to prove that states have a positive duty to take collective action}

sanctions against inaction by an international organization like the United Nations are almost impossible to determine or even imagine in international law. At best, third parties may consider protesting against the inaction, but if states in the international community do not live up to their responsibility to protect, existing international law is unable to coerce these states to take collective action. ${ }^{8}$

In addition, none of these four main documents, which the responsibility to protect concept is based on, can be regarded as generating binding international law. According to Article 38(1) of the Statute of the International Court of Justice, which defines the traditional sources of international law, only international conventions, international custom, general principles of law, judicial decisions and scholarly writings of respected legal scholars can generate binding international law. ${ }^{9}$ Since none of these four documents are considered sources of international law, they do not create any kind of legally binding obligation on states. This means states do not have any international legal duty to take action on a state that has failed to protect its citizens.

Moreover, there is weak evidence suggesting that states should take collective action under Chapter VII of the UN Charter to enforce the responsibility to protect. The responsibility of a state to protect its own citizens is clearly explicated in paragraph 138 of the Outcome Document. Paragraph 139 also distinctly articulates that foreign states should assist a state to fulfill its primary responsibility to protect through measures short of the use of force. However, the statement on the responsibility to take collective action is much more reserved. Paragraph 139 states: "We are prepared to take collective action, in a timely and decisive manner, through the Security Council, in accordance with the Charter, including Chapter VII, on a case-by-case basis..."10 According to the text, foreign states merely reaffirm that they are prepared to take collective action, which suggests their engagement is more voluntary than mandatory. Furthermore, collective action will be taken on a case-by-case basis, which undermines any idea that states have a systematic duty to take collective action. ${ }^{11}$

The only hope that the responsibility to protect may become part of international law in the future is if the concept is accepted as customary international law. According to Article 38(1) of the Statute of the International Court of Justice, customary international law is defined as "evidence of a general practice accepted as law". International customs are evaluated based on two components: the objective measurement of state practice, and the subjective measurement of opinio juris. State practice looks at the uniformity and duration of how states have applied the custom, and opinio juris measures whether states perceive this legal custom as law, and view the practice of the custom as part of their 
legal obligation.

Yet, the future of the responsibility to protect as an international custom is dim. Primarily, it has suffered from inconsistent state practice, and an unclear definition of what are the legal obligations for states creates a weak sense of opinio juris. The responsibility to protect has been invoked in nine different cases and there has been no consensus on what is a legitimate invocation of the responsibility to protect. ${ }^{12}$ For example, Russia invoked the responsibility to protect its citizens in 2008 to justify its military action in Georgia. Russian claims were widely rejected by governments. The responsibility to protect was also invoked in 2008 by France and some NGO advocates to rally action from the international community to respond to the cyclone-related humanitarian disaster in Myanmar. The debates reached a conclusion that the responsibility to protect was not applicable to natural disasters. While the responsibility to protect invoked during the election violence in Kenya in 2007 proved to be a success, ${ }^{13}$ the appeals to the responsibility to protect have been inconsistent.

\section{III.}

Given the weak legal pull of the responsibility to protect, the question that naturally follows is this, should the responsibility to protect be enshrined in international law? But the question we should ask is, do we want to enshrine the responsibility to protect in international law? In fact, enshrining the responsibility to protect in international law may endanger the stability of the international system.

To legalize the responsibility to protect would be an enormous challenge to existing norms in international relations. Primarily, it has to contend with one of the most sacrosanct norms in international relations, which is the principle of state sovereignty. Since the Peace of Westphalia of 1648, two principles have formed the basis of the modern international system. First, the concept of state sovereignty, which is a nation-state ruled by a government of its own, and second, the concept of territorial integrity, the idea that borders are secure between states. These principles are enshrined in Article 2(4) of the UN Charter, which forbids "the threat or use of force against the territorial integrity or political independence of any state." ${ }^{14}$ It is a difficult task to balance this idea with the responsibility to protect, which allows foreign states to intervene when necessary to protect civilians. Based on the responsibility to protect, state sovereignty is not an inherent right of statehood, but a positive right earned by responsible governments that protect their populations. ${ }^{15}$ To encourage the application of the responsibility to protect means revising the widely-accepted norm of state sovereignty

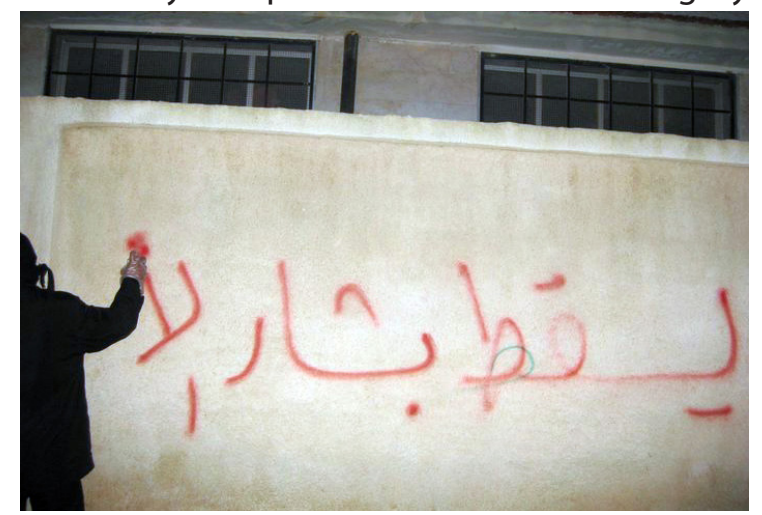

Graffiti in Syria reading "Down with Bashar al-A[ssad]"

and putting in place a new definition of state sovereignty, which is extremely difficult to do given the long history of the current definition of state sovereignty.

The case of Libya presents a great example to illustrate the dangerous precedents that the international community is setting that could threaten the future stability of the international system. Protests began on 15 February 2011 in Libya. On 20 February, Human Rights Watch reported that 233 civilians had died over the 4 days since protests began and that government troops were indiscriminately targeting civilians. ${ }^{16}$ Despite the fact that the level of atrocities was drastically lower than in Syria, the United Nations and the international community responded immediately to the situation in Libya. Within 11 days, on 26 February, the United Nations Security Council 
unanimously adopted Resolution 1970 reaffirming Libya's "responsibility to protect its population", ${ }^{\prime 17}$ the first time that the doctrine of responsibility to protect was invoked since 2006 regarding the situation in Darfur, Sudan. Shortly after a month of protests, on March 17, the Security Council passed Resolution 1973 sanctioning a no-fly zone to protect civilians and authorizing member states to take "all necessary measures to protect civilians"18 with Secretary-General Ban Kimoon affirming "clearly and unequivocally, the international community's determination to fulfill its responsibility to protect civilians from violence perpetrated upon them by their own government." ${ }^{19}$ Two days later, on March 19, a multi-state coalition led by NATO began

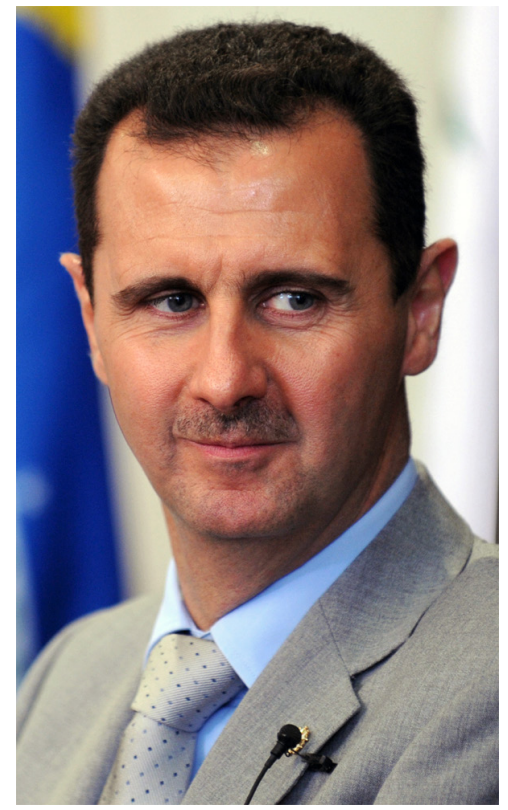

Syrian President Bashar Al-Assad

a military intervention in Libya to implement Resolution 1973. With regards to the situation in Libya, foreign states acted decisively, even when evidence about human rights violations was only just emerging. States were willing to use force collectively and prevent Gaddafi from inflicting further mass violence on civilians.

In Libya, the responsibility to protect was quickly invoked, and military action was taken immediately when it was determined necessary by the Security Council. As a result, many deaths and injuries of civilians were prevented. From a moral point of view, the international community was successful in preventing a humanitarian disaster. Stewart Patrick of Council on Foreign Relations argues that the intervention was the "first unambiguous military enforcement of the Responsibility to Protect norm" and that "Qaddafi's utter defeat seemingly put new wind in the sails of humanitarian intervention."20 However, from a legal point of view, the case of Libya set a dangerous precedent because it signaled to states that in the future, the right to sovereignty could be lost if the international community decided to remove that right. This concern particularly troubles emerging states, notably the BRICS (Brazil, Russia, India, China and South Africa) in the international system. India's U.N. ambassador, Hardeep Singh Puri has said, "Libya has given R2P a bad name."21 South African diplomats also expressed similar concerns, saying that they were indignant that the West ignored calls by the African Union for a cease-fire. $^{22}$

The Libya operation is significant because emerging countries such as BRICS express a fear shared by weaker states that their statehood would be undermined if the responsibility to protect becomes a robust norm in international law. While the Security Council passed Resolution 1973, the decision to intervene and the subsequent expansion of NATO activities beyond the UN mandate was diplomatically controversial. All the BRICS except South Africa, and Germany abstained from the original UN mandate. South Africa supported the mandate on the condition that the resolution was only used to protect civilians and ensure the delivery of humanitarian aid..$^{23}$ Furthermore, NATO's decision to pursue regime change incited disagreement and frustration among these states. Russia and South Africa accused NATO of overstepping its authority in pursuing regime change in Libya. ${ }^{24}$ Meanwhile, China demanded that Libyan sovereignty be respected in the process of finding a peaceful solution to the crisis, ${ }^{25}$ at the same time, Brazil 
and India expressed opposition to NATO air strikes.

The BRICS reluctance to authorize intervention in Libya reflects a concern about state sovereignty, which should not be ignored. These states feared giving support to the responsibility to protect, because it would contribute to the weakening of state sovereignty. Creating regime change by removing Gaddafi was proof that the value of sovereignty was being undermined. The BRICS did not want other states to utilize the responsibility to protect argument to justify an intervention on humanitarian basis, while harboring other political intentions such as regime change. Adopting the responsibility to protect as international law could transform the way states interact, which has primarily been guided by the principle of non-interference. "Sovereignty has underwritten international order primarily by enshrining the doctrine of non-intervention in the internal affairs of states as an essential ingredient of international society. While this may not have prevented interventions in the past, it has acted quite effectively as a normative requirement by forcing potential or actual interveners to justify their actions before their sovereign, and legally equal, peers." ${ }^{\prime 2}$ In the international system, states are legally equal based on the shared concept of state sovereignty. Enshrining the responsibility to protect in international law means changing the 'normative requirement' that governed intervention. This change could make it easier to intervene in the internal affairs of another sovereign state, and potentially lead to more instability and conflict in the international system.

\section{IV.}

Other considerations would also problematize the legalization of the responsibility to protect. If the responsibility to protect were to be enshrined in international law, it would create legal contradictions. The UN Charter's purpose was to limit the legitimate pretexts for states to engage war to either self-defense or collective security. Therefore, the Charter is silent on the question whether states can use military force to address a humanitarian crisis occurring in another sovereign state. ${ }^{27}$ By enshrining the responsibility to protect in international law, it would remove the Charter's silence on the use of military force for humanitarian purposes, but it would go against the Charter's original purpose, which was to limit the use of force to cases of self-defense and collective security. It would potentially open the floodgates for states to justify the use of force in the guise of humanitarian support.

Second, there is little utility in enshrining the responsibility to protect in international law. The responsibility to protect is a broad concept that involves

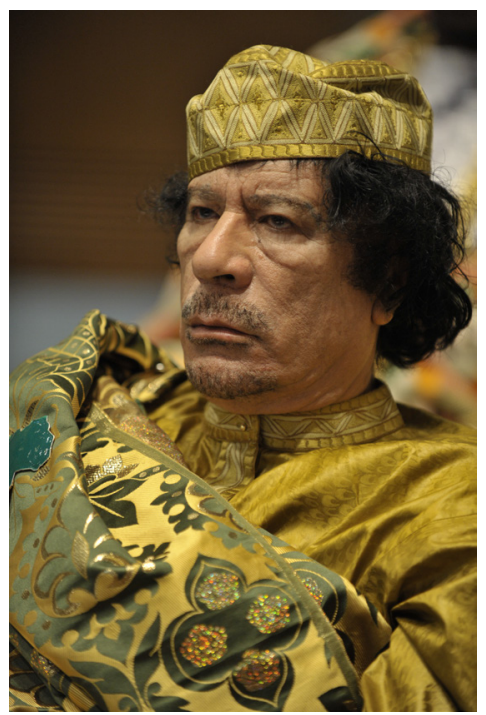

Former Libyan ruler Muammar Gaddafi

the responsibility to prevent atrocities from occurring, and reacting decisively if atrocities occur, and to rebuild after atrocities have halted. ${ }^{28}$ The problem is how to make each step a legal responsibility for states in the international system. Instead of treating the responsibility to protect as a legal concept that should be eventually adopted as international law, it would be more helpful to treat it as a catalyst for further action by the international community to create legal instruments that bind states to specific responsibilities under 
the umbrella concept of the responsibility to protect.

The responsibility to protect received unanimous adoption at the 2005 UN World Summit and was reaffirmed twice by the UN Security Council. By taking this consensus as a beginning, international community can begin to create new and specific legal regimes targeting the crimes specified in the responsibility to protect. This is more useful than adopting a broad and multifaceted concept such as the responsibility to protect as law.

The origins of international human rights law provide a great example of how to work on the existing consensus states share on the responsibility to protect. In 1948, the Universal Declaration of Human Rights was adopted unanimously by the United Nations General Assembly, where member states committed themselves and their people to secure the recognition and observance of the human rights specified in the Declaration. Importantly, the Declaration was a declaration and not a treaty, which meant that it was not a legally binding document, though it is generally accepted as customary international law given its unanimous passage. However, the takeaway point is that while the Declaration did not legally bind states to implement policies that respect, protect and fulfill human rights, it became a starting point for contemporary human rights regimes by triggering the creation of various United Nations and regional human rights covenants and international treaties which were legally binding.

The Declaration was the foundation for two UN human rights covenants, the 1966 International Covenant on Civil and Political Rights, and the 1966 International Covenant on Economic, Social and Cultural Rights. Other international treaties inspired from the Declaration include: the 1965 International Convention on the Elimination of All Forms of Racial Discrimination, the 1979 Convention on the Elimination of All Forms of Discrimination Against Women, the 1984 Convention
Against Torture and Other Cruel, Inhuman, or Degrading Treatment or Punishment, the 1989 Convention of the Rights of the Child, and the 1990 International Convention on the Protection of the Rights of all Migrant Workers and the Members of their Families. The Declaration has also spurred the adoption of three regional human rights conventions, namely the 1950 European Convention for the Protection of Human Rights and Fundamental Freedoms, the 1969 American Convention on Human Rights, and the 1981 African Charter on Human and Peoples Rights.

A better way to enshrine the international community's aspirations to protect civilians from the four crimes: genocide, war crimes, crimes against humanity and ethnic cleansing is to generate specific treaties that prevent and punish these crimes. Genocide has been outlawed with the passage of the Universal Declaration of Human Rights and the Convention on the Prevention and Punishment of the Crime of Genocide in 1948. Similarly, war crimes, crimes against humanity and ethnic cleansing should deserve their own treaties that prevent and punish any person, group or government that commit these crimes.

\section{Conclusion}

Based on the existing body of international law today, while states have the moral imperative, they do not have the legal duty to take action against a state that has failed to uphold its responsibility to protect its citizens. The documents which "responsibility to protect" is based on are not considered authoritative sources of international law. Therefore, even if states agree to the concept, it does not mean there exists a corresponding legal obligation to fulfill the responsibility to protect. Furthermore, the argument to use force collectively by the international community against violators of human rights law is weak. It appears that the international community intended for engagement to be voluntary and evaluated on a case-by-case 
basis. Finally, even if states decide not to fulfill their responsibility and do not take action against violators, they are not sanctioned or punished for noncompliance.

While enshrining the responsibility to protect in international law seems like an easy remedy to the lack of legal obligation on states to take action, it could potentially destabilize the international system by undermining the norm of state sovereignty. Sovereignty has guided how states interact with each other for the past four centuries since the Peace of Westphalia. BRICS' reluctance to support the responsibility to protect in the case of Libya demonstrates a legitimate concern about upholding state sovereignty when considering the long-run stability of the international system. While the responsibility to protect is a morally appealing concept, it should not be enshrined in international law because the benefits of having the responsibility to protect as an international law do not outweigh its relative costs. In the short run, we may reduce the level of civilian casualties in humanitarian conflicts. However, in the long run, more deaths could result due to the potential instability generated by the weakened norm of state sovereignty, which make interventions more likely and common. Even more significantly, accepting the weakened form of state sovereignty under the responsibility to protect will fundamentally alter the way states interact each other. States can no longer be legally equal peers if the sovereignty of some states is less respected than others.

\section{Endnotes}

12005 World Summit Outcome, GA Res. 60/1 (Oct 24 2005)

2 Ban Ki-moon, Implementing the Responsibility to Protect: Report of the Secretary-General, A/63/677, January 12, 2009.

3 Exec. Order No. PSD-10 (2011).

4 International Commission on Intervention and State Sovereignty, The Responsibility to Protect (2001)

5 A More Secure World: Our Shared Responsibility, Report of the High-Level Panel on Threats, Challenges and Change, UN Doc. A/59/565 (2004)

6 In Larger Freedom: Towards Development, Security and Human Rights for All, Report of the Secretary-General, UN Doc. A/59/2005 (2005)

72005 World Summit Outcome, GA Res. 60/1 (Oct 24 2005)

8 Stahn, Carsten. "Responsibility to Protect: Political Rhetoric or Emerging Legal Norm?" The American Society of International Law 101.1 (2007): 117.

9 Statute of the International Court of Justice, art. 38, para. 1.

102005 World Summit Outcome, GA Res. 60/1 (Oct 24 2005)

11 Stahn, 109.

12 Bellamy, Alex J. “The Responsibility to Protect Five Years On.” Ethics \& International Affairs 24.2 (2010): 149.

13 Bellamy, 153.

14 U.N. Charter, art. 2, para. 4. 
15 Ban Ki-moon, Responsibility to Protect Faces Urgent Test 'Here and Now': Report of the Secretary-General, GA/11271, September 5, 2012.

16 "Libya: Governments Should Demand End to Unlawful Killings." Human Rights Watch. 20 Feb. 2011. Web. <http:// www.hrw.org/en/news/2011/02/20/libya-governments-should-demand-end-unlawful-killings>.

17 U.N. Security Council, 6491 st Meeting. "Resolution 1970 (2011) [Peace and security in Africa]" (S/RES/1970). 26 February 2011.

18 U.N. Security Council, 6498 ${ }^{\text {th }}$ Meeting. "Resolution 1973 (2011) [The situation in Libya]" (S/RES/1973). 17 March 2011.

19 Secretary-General. Department of Public Information. Secretary-General Says Security Council Action on Libya Affirms International Community's Determination to Protect Civilians From Own Government's Violence. United Nations Meetings Coverage \& Press Releases. 17 Mar. 2011. Web. <http://www.un.org/News/Press/docs/2011/sgsm13454.doc. htm>.

20 Patrick, Stewart. "Libya and the Future of Humanitarian Intervention: How Qaddafi's Fall Vindicated Obama and RtoP." Foreign Affairs. 25 Aug. 2011. Web. <www.foreignaffairs.com/articles/68233/stewart-patrick/libya-and-thefuture-of-humanitarian-intervention?page $=$ show $>$.

21 Bolopion, Philippe. "After Libya, the Question: To Protect or Depose?" Los Angeles Times. 25 Aug. 2011. Web. $<$ http://articles.latimes.com/2011/aug/25/opinion/la-oe-bolopion-libya-responsibility-t20110825>.

22 lbid.

23 Snyman, Henning. "A Reflection on South Africa's Engagements with the Middle East and North Africa." South African Institute of International Affairs. 26 July 2011. Web. <http://www.saiia.org.za/feature/a-reflection-on-southafrica-s-engagements-with-the-middle-east-and-north-africa.html>.

24 Pidd, Helen. “Nato Rejects Russian Claims of Libya Mission Creep." 15 Apr. 2011. Web. <http://www.guardian.co.uk/ world/2011/apr/15/nato-libya-rasmussen-medvedev-criticism>.

25 Wilkins, Brett. “China, India, Russia \& Turkey Among Nations Critical of Attack on Libya." Web log post. Moral Low Ground. 21 Mar. 2011. Web. <http://morallowground.com/2011/03/21/china-india-russia-turkey-among-nationscritical-of-attack-on-libya/>.

26 Ayoob, Mohammed. "Humanitarian Intervention and State Sovereignty." The International Journal of Human Rights 6.1 (2002): 81-102.

27 Welsh, Jennifer."Implementing the "Responsibility to Protect"' Oxford Institute for Ethics, Law and Armed Conflict 1 (2009): 2.

28 Ban Ki-moon, Implementing the Responsibility to Protect: Report of the Secretary-General, A/63/677, January 12, 2009.

Photo Credits: Wikimedia Commons 